\title{
Gaya Kepemimpinan Terhadap Motivasi Kerja Gen-Z (Studi Kasus pada Mahasiswa Politeknik Cendana Medan)
}

\author{
Timori Kansaki ${ }^{1}$, Ngajudin Nugroho ${ }^{*}$, Fauzi Akbar Maulana Hutabarat ${ }^{1}$, Elserra Siemin Ciamas ${ }^{1}$, Arwin $^{2}$ \\ ${ }^{1}$ Program Studi Manajemen Pemasaran, Politeknik Cendana, Medan, Indonesia \\ ${ }^{2}$ Program Studi Manajemen Perusahaan, Politeknik Cendana, Medan, Indonesia \\ Email: ${ }^{2, *}$ ngajudinnugroho.cendana@gmail.com
}

\begin{abstract}
Abstrak-Penelitian ini bertujuan untuk membuktikan secara empiris pengaruh gaya kepemimpinan terhadap motivasi kerja Generasi $-\mathrm{Z}$, metode yang di gunakan dalam penelitian ini adalah metode penelitian kuantitatif, penelitian ini dimaksudkan untuk membang un suatu gambaran terhadap fenomena yang berada dalam konteks penelitian yaitu kaum pemuda sekarang atau disebut juga generasi Z. studi ini di lakukan pada mahasiswa - mahasiswi politeknik cendana, pengumpulan data berupa kuesioner yang disebarkan kepada responden dengan sampel sebanyak 71 mahasiswa dan mahasiswi. Analisis data yang digunakan adalah analisis regresi linear berganda dengan bantuan perangkat lunak pengolah data, hasil penelitian ini menunjukkan bahwa secara simultan gaya kepemimpinan situasional dan gaya kepemimpinan otokratis berpengaruh secara signifikan terhadap motivasi kerja Generasi - Z. penelitian ini juga menghasilkan pengaruh secara parsial dari masing - masing variabel independen terhadap variabel dependen, kontribusi dari variabel - variabel independen yang disertakan dalam persamaan regresi terhadapa variabel bebas adalah sebesar $15.2 \%$ sisanya $84.8 \%$ dipengaruhi oleh variabel lain yang tidak termasuk ke dalam model penelitian ini.
\end{abstract}

Kata Kunci: Gaya Kepemimpinan; Motivasi Kerja; Generasi-Z

\begin{abstract}
This study aims to empirically prove the influence of leadership style on the work motivation of Generation - Z, the method used in this study is a quantitative research method, this research is intended to build a picture of the phenomenon that is in the context of research, namely youth today or also called Generation - Z. This study was conducted on sandalwood polytechnic students, collecting data in the form of questionnaires distributed to respondents with a sample of 71 students. The data analysis used is multiple linear regression analysis with the help of data processing software, the results of this study indicate that simultaneously situational leadership style and autocratic leadership style significantly influence work motivation of Generation Z. This study also produces a partial effect of each - each independent variable to the dependent variable, the contribution of the independent variables included in the regression equation to the independent variable is $15.2 \%$, the remaining $84.8 \%$ is influenced by other variables not included in this research model.
\end{abstract}

Keywords: Leadership Style; Work Motivation; Generation-Z

\section{PENDAHULUAN}

Setiap industri yang tumbuh sangat bergantung pada keahlian sumber energi manusia untuk menggunakan sumber energi yang terdapat di industri untuk melakukan tugas. Sumber Daya Manusia merupakan aset perusahaan yang sangat penting dalam suatu kegiatan organisasi atau perusahaan (Han, Erviriani, Siregar, Ivone, \& Lisa, 2019). Pada realitanya banyak karyawan yang kurang motivasinya sehingga merasa acuh tidak acuh terhadap pekerjaannya apalagi terdapat pula yang merasa tertekan, orang yang motivasinya yang rendah tidak dapat bekolaborasi dengan team, sehingga sangat sedikit karyawan yang betul- betul mempunyai mutu yang baik. Apalagi dengan sifat pimpinan yang tidak efisien dan efektif, membuat motivasi kerja karyawan menurun. Aktifitas produktif diperlukan oleh manajemen perusahaan guna meningkatkan kinerja perusahaan sehingga dapat memenangkan persaingan (Wilinny, Halim, Sutarno, Nugroho, \& Hutabarat, 2019). Hal ini juga di dukung dan di buktikan dari hasil penelitian (Simanjuntak, 2020) menyatakan adanya pengaruh signifikan motivasi kerja terhadap kinerja karyawan, Jadi menurunnya motivasi kerja menurun juga pula kinerja karyawan. Diharapkan lewat penciptaan gaya kepemimpinan yang efisien dan efektif dapat membuat dampak terhadap motivasi kerja, terutama motivasi kerja generasi - Z. Triton menyatakan bahwa motivasi merupakan bagian dari pengembangan pribadi sangat penting. Hampir seluruh dunia dan para pemimpin nasional memiliki kemampuan yang tinggi untuk membakar motivasi (Nugroho, Chua, Arwin, Han, \& Wilinny, 2019). Berdasarkan hasil survei angkatan kerja nasional (sakernas) tahun 2019, Generasi - Z yang lahir di atas tahun 1997 telah mengisi kurang lebih 12 juta posisi produktif dan siap kerja di indonesia Menariknya, dari 12 juta generasi z yang produktif dan siap kerja tersebut, 57\% dari mereka telah menjadi pekerja tetap. Angka ini merupakan angka persentase tertinggi jika dibandingkan dengan generasigenerasi sebelumnya. Dengan data sakernas sebelumnya kita dapat mengetahui bahwa pekerja yang berusia sekitar 1824 tahun telah mengisi 50\% lebih lapangan pekerjaan yang di indonesia dan pastinya sebagian dari pekerja tesebut berstatus mahasiswa - mahasiswi.

Hasil prapenelitian dengan jumlah responden 40 mahasiswa - mahasiswi Politeknik cendana benunjukkan bahwa 85\% mahasiswa - mahasiswi menyatakan setuju bahwa terdapat pengaruh gaya kepemipinan terhadap motivasi kerja di tempat mereka berkerja, hal ini sejalan dengan hasil penelitian (Ningsih, 2016) yang menunjukkan bahwa kepemimpinan mempunyai pengaruh sekaligus hubungan yang positif terhadap motivasi kerja karyawan.

\section{KERANGKA TEORI}

Gaya kepemimpinan adalah pola perilaku dan strategi yang dianut oleh pemimpin yang terlihat atau tidak terlihat oleh orang lain. Menurut Thoha, Gaya kepemimpinan adalah perilaku atau cara yang dipilih yang digunakan pemimpin dalam 
mempengaruhi pikiran, perasaan sikap, dan perilaku para anggota organisasi atau bawahannya"(Fajrin \& Susilo, 2018). Motivasi kerja merupakan suatu kondisi yang menyebabkan individu (karyawan) berusaha keras untuk mencapai tujuan bisnis yang ditentukan oleh kebutuhan pribadinya. Ada 17 jenis gaya kepemimpinan situasional, paternalistik, etis, spiritual, autentik, otokratis, demokratis, transfomasional, transaksional, partisipatif, delegatif, mentor/coaching, digital, lintas budaya, kharismatik, pelayan, dan resonan (Demirtas \& Karaca, 2020). Dalam penelitian ini hanya menfokuskan pada gaya kepemimpinan situasional dan gaya kepemimpinan otokratis

Gaya kepemimpinan situasional disebut juga kepemimpinan darurat atau kepemimpinan complexity. Gaya ini mengasumsikan bahwa tidak ada gaya kepemimpinan yang cocok untuk semua manajer dalam semua situasi. Oleh karena itu, gaya kepemimpinan situasional harus didasarkan pada pertimbangan seperti pemimpin, pengikut, dan keadaan (dalam hal struktur tugas, peta kekuasaan, dan dinamika tim) dan menerapkan gaya tertentu. Ini sering disebut hukum situasi.

Gaya kepemimpinan Otokrasi disebut juga kediktatoran atau kepemimpinan terarah. Individu yang mengambil pendekatan ini tidak berkonsultasi dengan mereka yang harus melaksanakan keputusan atau mereka yang terpengaruh oleh keputusan saat membuat keputusan. Mereka menentukan apa yang harus dilakukan orang lain dan mengharapkan mereka untuk mematuhinya. Kritiknya adalah bahwa metode ini tidak akan efektif dalam jangka panjang, karena akan timbulnya rasa memberontak kepada pemimpin.

Istilah motivasi berasal dari kata latin yaitu "movere" yang berarti "dorongan" atau "daya penggerak". motivasi merupakan kondisi atau energi yang menggerakan diri karyawan yang terarah atau tertuju untuk mencapai tujuan organisasi perusahaan (Fajrin \& Susilo, 2018). Sikap psikologis karyawan yang profesional dan termotivasi terhadap situasi kerja meningkatkan motivasi mereka untuk mencapai produktivitas maksimum. Jadi motivasi itu tentang bagaimana menginspirasi semangat kerja bawahan agar mau bekerja keras dan menggunakan segala keahlian dan kemampuannya untuk mencapai tujuan perusahaan. Dapat di simpulkan bahwa motivasi kerja merupakan salah satu faktor penentu keberhasilan tujuan perusahaan.

Generasi $\mathrm{z}$ atau gen $\mathrm{z}$ disebut sebagai generasi yang lahir setelah generasi y. Kumpulan orang yang termasuk ke dalam generasi ini adalah mereka yang lahir di tahun 1995 sampai dengan 2010. Jadi bila anda lahir di rentang waktu itu maka anda juga turut termasuk ke dalam generasi $\mathrm{z}$.

\section{METODOLOGI PENELITIAN}

\subsection{Metode Penelitian}

Metode yang digunakan dalam penelitian ini adalah metode Kuantitaif dengan survei Metode ini memiliki sifat yang sistematis dan menggunakan model-model yang bersifat matematis sehingga hasil yang di dapat memuaskan. Metode kuantitatif adalah metode yang berdasar filsafat positivisme bertujuan menggambarkan dan menguji hipotesis yang dibuat peneliti. Metode kuantitatif ini merupakan data yang karakteristiknya dalam bentuk angka atau numerik (Dhira, Alexandro, \& Putri, 2021).

\subsection{Populasi dan Sampel}

Populasi penelitian yang dimaksud disini adalah Mahasiswa - Mahasiwi Politeknik Cendana angkatan 2018 - 2019. Sedangkan sampel dalam penelitian ini adalah Quota Sampling, sampel kuota adalah teknik untuk menentukan sampel dari populasi yang mempunyai ciri-ciri tertentu sampai jumlah (kuota) yang diinginkan (Sugiyono, 2017). Berikut rincianya:

Tabel 1.Sampel Penelitian

\begin{tabular}{cccc}
\hline No & Nama Kelas & Jumlah & PenentuanSampelKuota \\
\hline 1 & Mexico & 46 & $46 / 241 \times 71=14$ \\
2 & Alaska & 48 & $48 / 241 * 71=14$ \\
3 & Korea & 47 & $47 / 241 * 71=14$ \\
4 & Diamond & 17 & $17 / 241 * 71=5$ \\
5 & Reg Plus & 25 & $25 / 241 * 71=7$ \\
6 & Regular & 39 & $39 / 241 * 71=11$ \\
7 & MO Victory & 19 & $19 / 241 * 71=6$ \\
\hline & TOTAL & 241 & 71 \\
\hline
\end{tabular}

\subsection{Metode Analisis Data}

Dalam penelitian ini ada beberapa analisis data yang di pakai antara lain adalah analisis kolerasi, Analisis ini digunakan untuk mengetahui derajat atau kekuatan hubungan antara variabel Independen dan variabel Dependen secara bersamaan. Berikut kriteria interval koefisien kolerasi.

Tabel 2. Kriteria Interval Koefisien

\begin{tabular}{cc}
\hline Invertal Koefisien & Tingkat Realibilitas \\
\hline $0,00-0,199$ & SangatRendah \\
$0,00-0,399$ & Rendah \\
\hline
\end{tabular}




\begin{tabular}{cc}
\hline Invertal Koefisien & Tingkat Realibilitas \\
\hline $0,40-0,599$ & Sedang \\
$0,60-0,799$ & Kuat \\
$0,80-1,000$ & SangatKuat \\
\hline
\end{tabular}

Metode yang digunakan untuk penelitian ini menggunakan Koefesien diterminasi, analisis dengan simbol $\mathrm{R}^{\wedge} 2$ merupakan proporsi variabilitas dalam suatu data yang dihitung didasarkan pada model statistik. Definisi berikutnya menyebutkan bahwa $\mathrm{R}^{\wedge} 2$ merupakan rasio variabilitas nilai-nilai yang dibuat model dengan variabilitas nilai data asli. Analisis koefisien determinasi digunakan untuk menjelaskan seberapa besar pengaruh variabel (X1) dan (X2) terhadap variabel (Y) secara simultan (Firmansyah \& Sinambela, 2020), rumus untuk menghitung koefisien determinasi yang telah dirumuskan sebagai berikut:

Keterangan

$$
K d=(R)^{2} \times 100 \%
$$

$\mathrm{Kd} \quad=$ Koefisien Determinasi

$\mathrm{R}^{2}=$ Koefisien Kolerasi Ganda

$100 \%=$ Pengali yang menyatakan dalam prentase

Untuk metode yang ketiga menggunakan analisis regresi linier berganda berfungsi untukmeramalkan bagaimana keadaan (naik turunnya) variabel dependen (kriterium), bila dua ataulebih variabel independen sebagai faktor prediator dimanipulasi (dinaik turunkan nilainya).Analisis regresi berganda dilakukan bila jumlah variabel independennya minimal 2 (dua). Jadi Pada penelitian ini kolerasi di gunakan adalah analisis regresi liner berganda (Gofur, 2018).

\subsection{Hipotesis Penelitian}

$\mathrm{H}_{0}=$ Gaya Kepemimpinan Situasional dan Gaya Kepemimpinan Otokrasi tidak memiliki pengaruh terhadap Motivasi Kerja Generasi -Z.

$\mathrm{H}_{\mathrm{a}}=$ Gaya Kepemimpinan Situasional dan Gaya Kepemimpinan Otokrasi memiliki pengaruh terhadap Motivasi Kerja Generasi -Z.

\section{HASIL DAN PEMBAHASAN}

\subsection{Hasil Uji Korelasi}

Hasil Uji kolerasi secara parsial

Tabel 3. Hasil Uji Kolerasi Gaya Kepemimpinan Situasional (X1) dan Motivasi Kerja (Y)

\begin{tabular}{llrr}
\hline & \multicolumn{1}{c}{ Correlations } & $\begin{array}{c}\text { G.K. } \\
\text { Situasional }\end{array}$ & $\begin{array}{c}\text { Motivasi } \\
\text { Kerja }\end{array}$ \\
\hline G.K. & Pearson Correlation & 1 & $0,290^{*}$ \\
Situasional & Sig. (2-tailed) & & 0,014 \\
& N & 71 & 71 \\
Motivasi & Pearson Correlation & $0,290^{*}$ & 1 \\
Kerja & Sig. (2-tailed) &, 014 & \\
& N & 71 & 71 \\
\hline
\end{tabular}

Sumber : hasil pengolahan data

Berdasarkan tabel diatas adanya korelasi antara Gaya Kepemimpinan Situasional(X1) dengan Motivasi Kerja(Y) karena nilai Signifikasi $0,014<0,05$. sehingga dikatakan secara parsial adanya hubungan di antara kedua variabel secara positif dengan derajat korelasi 0,290(rendah).

Tabel 4. Hasil Uji Kolerasi Gaya Kepemimpinan Otokratis (X2) dan Motivasi Kerja(Y)

\begin{tabular}{llrr}
\hline & \multicolumn{1}{c}{ Correlations } & $\begin{array}{c}\text { G.K. } \\
\text { Otokratis }\end{array}$ & \multicolumn{1}{c}{$\begin{array}{c}\text { Motivasi } \\
\text { Kerja }\end{array}$} \\
\hline G.K. & Pearson Correlation & 1 & $-0,325^{* *}$ \\
Otokratis & Sig. (2-tailed) & & 0,006 \\
& N & 71 & 71 \\
Motivasi & Pearson Correlation & $-0,325^{* *}$ & 1 \\
Kerja & Sig. (2-tailed) & 0,006 & \\
& N & 71 & 71 \\
\hline
\end{tabular}

Sumber : hasil olah data penulis 
Berdasarkan tabel diatas adanya korelasi antara Gaya Kepemimpinan Otokratis(X2) dengan Motivasi Kerja(Y) karena nilai signifikasi $0,006<0,05$. sehingga dikatakan secara parsial adanya hubungan di antara kedua variabel secara negatif dengan derajat korelasi $-0,325$ (rendah)

\subsection{Hasil Uji Kolerasi Secara Simultan}

Tabel 5. hasil Uji kolerasi Berganda/Simultan

\begin{tabular}{|c|c|c|c|c|c|c|c|c|c|}
\hline Model & $\mathrm{R}$ & R Square & Adjusted R Square & Std. Error of the Estimate & R Square Change & F Change & df1 & df2 & Sig. F Change \\
\hline 1 & $0,390^{\mathrm{a}}$ & 0,152 & 0,127 & 5,079 & 0,152 & 6,090 & 2 & 68 & 0,004 \\
\hline
\end{tabular}

Berdasarkan tabel diatas adanya korelasi karena nilai signifikasi 0,004 $<0,05$ sehingga dikatakan Gaya Kepemimpinan Situasional(X1) dan Gaya Kepemimpinan Otokratis(X2) secara simultan berhubungan dengan Motivasi Kerja(Y) sebesar 0,390 (Rendah).

4.3 Hasil Uji Regresi Linear Berganda

Tabel 6. Hasil Uji Regresi Linear Berganda

\begin{tabular}{|c|c|c|c|c|c|c|}
\hline \multicolumn{7}{|c|}{ Coefficients $^{\mathbf{a}}$} \\
\hline & Model & $\begin{array}{l}\text { Unstandardized } \\
\text { B }\end{array}$ & $\begin{array}{l}\text { Coefficients } \\
\text { Std. Error }\end{array}$ & $\begin{array}{c}\text { Standardized Coefficients } \\
\text { Beta }\end{array}$ & $\mathrm{t}$ & Sig. \\
\hline & (Constant) & 36,019 & 3,746 & & 9,615 & 0,000 \\
\hline 1 & $\begin{array}{l}\text { G.K. Situasional } \\
\text { G.K. Otokratis }\end{array}$ & $\begin{array}{c}0,200 \\
-0,330\end{array}$ & $\begin{array}{l}0,103 \\
0,141\end{array}$ & $\begin{array}{c}0,223 \\
-0,269\end{array}$ & $\begin{array}{r}1,932 \\
-2,333\end{array}$ & $\begin{array}{l}0,058 \\
0,023\end{array}$ \\
\hline
\end{tabular}

Sumber : hasil olah data penulis

Berdasarkan hasil pengolahan data seperti terlihat pada Tabel diatas maka diperoleh persamaan regresi linear berganda sebagai berikut:

Nilai Konstanta Sebesar 36,019 yang artinya apabila tidak terjadi peningkatan gaya kepemimpinan situasional dan gaya kepemimpinan otokratis maka motivasi kerja generasi-z adalah 36,019. Koefisien dari variable gaya kepemimpinan situasional (X1) adalah sebesar 0,200 yang berate setiap adanya perubahan kepemimpinan maka motivasi kerja meningkat atau menurun sebesar 0,200. Koefisien dari variabel gaya kepemimpinan otorkatis (X2) adalah sebesar -0,330 yang berarti setiap adanya perubahan kepemimpinan maka motivasi kerja meningkat atau menurunsebesar -0,330

\subsection{Hasil Uji koefisien Determinasi}

Tabel 7. Hasil Uji Koefisien Determinasi

\begin{tabular}{lcccc}
\hline \multicolumn{4}{c}{ Model Summary } \\
Model & R & R Square & $\begin{array}{c}\text { Adjusted R } \\
\text { Square }\end{array}$ & $\begin{array}{c}\text { Std. Error of the } \\
\text { Estimate }\end{array}$ \\
\hline 1 & $0,390^{\mathrm{a}}$ & 0,152 & 0,127 & 5,079 \\
a. Predictors: (Constant), G.K. Situasional, G.K. Otokratis \\
b. Dependent Variable: MotivasiKerja
\end{tabular}

Sumber : hasil olah data penulis

Berdasarkan Tabel diatas dapat dilihat nilai $R$-square adalah 0,152 atau sama dengan 15,2\% artinya bahwa Gaya Kepemimpinan Situasional dan Gaya Kepemimpinan Otokratis mempengaruhi Motivasi Kerja sebesar 15,2\% sisanya $84.8 \%$ dipengaruhi oleh variabel lain yang tidak termasuk kedalam model penelitian ini.

\section{KESIMPULAN}

Setelah dilakukan pengujian dan pembahansan kita dapat menyimpulkan pernyataan, secara parsial adanya signifikansi antara gaya kepemimpinan situasional terhadap motivasi kerja generasi - $\mathrm{z}$ mahasiswa dan mahasiswi Politeknik cendana secara positif dengan derajat korelasi rendah $(0,290)$ untuk gaya kepemimpinan otokratis juga berpengaruh signifikan terhadap motivasi kerja generasi - $\mathrm{z}$ mahasiswa dan mahasiswi Politeknik cendana secara negatif dengan derajat kolerasi rendah $(-0,325)$. Untuk secara simultan gaya kepemimpinan situasional dan gaya kepemimpinan otokratis juga berpengaruh signifikan terhadap motivasi kerja generasi - z mahasiswa dan mahasiswi Politeknik cendana dengan derajat kolerasi rendah (0,390). Nilai R Square (R2) atau koefisien determinasi yang diperoleh sebesar 0,152 atau sama dengan 15,2\% artinya bahwa Gaya Kepemimpinan Situasional dan Gaya Kepemimpinan Otokratis mempengaruhi Motivasi Kerja sebesar $15,2 \%$ sisanya $84.8 \%$ dipengaruhi oleh variabel lain yang tidak termasuk ke dalam model penelitian ini. 


\section{DAFTAR PUSTAKA}

Demirtas, O., \& Karaca, M. (2020). A Handbook of Leadership Styles. Newcastle: Cambridge Scholars Publishing Lady.

Dhira, B. N., Alexandro, R., \& Putri, W. U. (2021). Pengaruh Mata Kuliah Kewirausahaan Terhadap Minat Berwirausaha Pada Mahasiswa Pendidikan Ekonomi. Edunomics Journal, 2(2), 81-86.

Fajrin, I. Q., \& Susilo, H. (2018). Pengaruh Gaya Kepemimpinan Terhadap Kinerja Karyawan dengan Motivasi Kerja sebagai Variabel Intervening (Studi pada Karyawan Pabrik Gula Kebon Agung Malang). Jurnal Administrasi Bisnis, 61(4), 117-124.

Firmansyah, I., \& Sinambela, R. T. (2020). Pengaruh Sistem Pengendalian Internal Terhadap Kualitas Laporan Keuangan Pada Badan Pengelolaan Keuangan Dan Aset Daerah Provinsi Jawa Barat. Logistic And Accounting Development Journal, 1(1), 1-11.

Gofur, A. (2018). Analisis Pengaruh Kualitas Layanan dan Harga Terhadap Kepuasan Pelanggan. Jurnal Riset Manajemen Dan Bisnis, $4(1), 37-44$.

Han, W. P., Erviriani, E., Siregar, A. R. A., Ivone, I., \& Lisa, L. (2019). Analisis Kepuasan Kerja dan Lingkungan Kerja Karyawan di Sekolah EN Mandarin - Medan. Jurnal Ilmiah Maksitek, 4(2).

Ningsih, A. R. (2016). Pengaruh Kepemimpinan Terhadap Motivasi Kerja Karyawan Pada PDAM Kota Madiun. EQUILIBRIUM : Jurnal Ilmiah Ekonomi Dan Pembelajarannya, 4(2), 192. https://doi.org/10.25273/equilibrium.v4i2.661

Nugroho, N., Chua, E., Arwin, A., Han, W. P., \& Wilinny, W. (2019). Analisis Motivasi Kerja Karyawan Bagian Pemasaran PT. Global Mitra Prima. Jurnal Ilmiah Kohesi, 3(3), 4.

Simanjuntak, P. A. (2020). Pengaruh Etos Kerja, Kepuasan Kerja, Sikap Kerja Dan Motivasi Kerja Terhadap Kinerja Pegawai Pada Kantor Pelayanan Pajak Pratama Medan Polonia. Manajemen Bisnis Jurnal Magister Manajemen, 2(1), 48-55.

Sugiyono. (2017). Metode Penelitian Pendidikan Pendekatan Kuantitatif, Kualitatif, dan R\&D. Bandung: Alfabeta.

Wilinny, W., Halim, C., Sutarno, S., Nugroho, N., \& Hutabarat, F. A. M. (2019). Analisis Komunikasi Di PT. Asuransi Buana Independent Medan. Jurnal Ilmiah Simantek, 3(1). 